\title{
Pengaruh Self-Attribution Bias, Mental Accounting, dan Familiarity Bias terhadap Pengambilan Keputusan Investasi Mahasiswa Akuntansi
}

\author{
Received: \\ 27 Juli 2020 \\ Revision \\ received: \\ 19 November \\ 2020 \\ Accepted: \\ 5 Desember \\ 2020
}

\author{
Novia Dwi Anggini, Cipto Wardoyo, dan Vega Wafaretta* \\ Jurusan Akuntansi, Fakultas Ekonomi, Universitas Negeri Malang
}

\begin{abstract}
:
There are many factors that influence investment decision making, including biased psychological factors that can make investors irrational. Therefore, the purpose of this study is to find out the effects of bias, namely self-attribution bias, mental accounting, and familiarity bias on investment decision making. The sample in this study were students who participated in several investment communities in Malang because students represented potential young investors to contribute in investing in the capital market. 288 questionnaires were distributed online and tested for multiple regression. The results of this study are self-attribution bias, mental accounting, and familiarity bias have positive effects on investment decision making. Confidence in self-sttributiony, consideration of costs and benefits, and the level of familiarity are the main factors that drive investment decision making.
\end{abstract}

Keywords: self-attribution bias, mental accounting, familiarity bias, investment decision making

\begin{abstract}
Abstrak:
Terdapat banyak faktor yang mempengaruhi pengambilan keputusan investasi, termasuk faktor psikologis yang bersifat bias yang dapat membuat investor menjadi irrasional. Oleh karena itu, tujuan penelitian ini adalah untuk mengetahui beberapa pengaruh bias, yaitu selfattribution bias, mental accounting, dan familiarity bias terhadap pengambilan keputusan investasi. Sampel dalam penelitian ini adalah mahasiswa yang mengikuti beberapa komunitas investasi di Kota Malang karena mahasiswa mewakili investor muda yang potensial untuk berkontribusi dalam berinvestasi di pasar modal. 288 kuesioner disebarkan secara online dan diuji regresi berganda. Hasil penelitian ini adalah self-attribution bias, mental accounting, dan familiarity bias berpengaruh positif terhadap pengambilan keputusan investasi. Kepercayaan atas kemampuan diri, pertimbangan biaya dan manfaat, serta tingkat keakraban menjadi faktor utama yang mendorong pengambilan keputusan investasi.
\end{abstract}

Kata kunci: self-attribution bias, mental accounting, familiarity bias, pengambilan keputusan investasi

\section{Pendahuluan}

Perkembangan investasi di pasar modal Indonesia semakin mengalami peningkatan. Pesatnya pertumbuhan investasi pasar modal dibuktikan oleh data Kustodian Sentra Efek Indonesia (KSEI) per Maret 2018 yang mencatat bahwa jumlah investasi saham di Indonesia mencapai 1,21 juta Single Individu Identification (SID) yang mana angka tersebut meningkat sebesar 8,34\% dibandingkan tahun 2017 yang hanya sebesar 1,12 juta SID (investasi.kontan.co.id, 2018).

Data tersebut menunjukkan bahwa masyarakat telah memiliki minat yang tinggi untuk melakukan investasi. Khusus untuk kalangan pemuda, mahasiswa menjadi salah satu kalangan yang memiliki minat 
tertinggi dalam melakukan investasi. Investor yang tercatat di pasar modal Indonesia didominasi oleh kaum milenial, khususnya mahasiswa. Hal ini tidak terlepas dari upaya yang dilakukan oleh BEI selaku pengelola efek dengan mengubah satuan pembelian saham yang awalnya minimal pembelian 1 lot adalah 500 lembar kini menjadi 100 lembar saja. Upaya tersebut dilakukan untuk menggaet lebih banyak investor muda, khususnya mahasiswa.

Untuk menjadi investor, mahasiswa perlu memiliki keahlian untuk mengambil keputusan investasi yang tepat. Keputusan investasi ini penting karena akan menentukan keuntungan yang akan diperoleh. Namun, dalam mengambil keputusan, tidak menutup kemungkinan seorang investor akan selalu melibatkan faktor psikologis dalam investasinya (Ratnadewi, 2014). Keterlibatan faktor psikologis inilah yang kemudian menyebabkan investor ketika mengambil keputusan cenderung tidak rasional dan dapat menyebabkan kesalahan dalam memprediksi dan menganalisis investasinya. Ketidakrasionalan investor ini selanjutnya dijelaskan oleh behavioral finance theory (Shefrin, 2002).

Adanya faktor psikologis dalam pengambilan keputusan investasi menyebabkan seorang investor akan berperilaku bias. Melalui bias inilah yang menyebabkan investor untuk berperilaku irasional ketika akan mengambil keputusan investasi. Perilaku pengambilan keputusan investasi yang irasional dapat disebabkan oleh beberapa faktor bias seperti self-attribution bias, mental accounting, dan familiarity bias.

Self-attribution bias menjelaskan bahwa investor menganggap keberhasilan yang mereka dapatkan merupakan kemampuan dan pengetahuan mereka sendiri, sedangkan kegagalan merupakan kesalahan faktor eksternal dan bukan dari diri mereka (Hsu dan Shiu, 2007). Mental accounting adalah perilaku investor yang selalu mempertimbangkan cost dan benefit dalam pengambilan keputusannya. Investor akan selalu berusaha mengevaluasi keuangannya dengan memberi kategori pada setiap investasinya agar memaksimalkan keuntungan di kemudian. Familiarity bias mengakibatkan investor akan mengambil keputusan yang berkaitan dengan sesuatu yang familier atau hanya pada sesuatu yang mereka kenali saja (Nofsinger, 2005).

Ketiga faktor tersebut, self-attribution bias, mental accounting, dan familiarity bias merupakan bias yang dapat berpengaruh kurang baik dalam pengambilan keputusan investasi seorang investor. Biasbias tersebut menyebabkan investor untuk berperilaku tidak sesuai dan pada akhirnya hanya akan memberikan kerugian pada diri investor sendiri. Apalagi investor muda yaitu mahasiswa yang berpotensi memiliki bias yang besar. Tidak menutup kemungkinan mahasiswa memiliki sikap atribusi terhadap diri yang besar, hanya fokus pada cost dan benefit, serta memiliki pengalaman yang terbatas. Kondisi tersebut dapat mengakibatkan munculnya self-attribution bias karena terlalu yakin pada diri sendiri, mental accounting yang hanya memperhitungkan untung dan rugi, serta familiarity bias yang hanya melibatkan sesuatu yang familier saja karena terbatasnya pengalaman mahasiswa.

Dengan demikian, penelitian ini menguji pengaruh ketiga faktor bias tersebut terhadap pengambilan keputusan investasi oleh mahasiswa di Kota Malang. Mahasiswa dipilih sebagai subjek yang mewakili kalangan akademisi untuk melakukan investasi di pasar modal, dengan pengalaman lebih sedikit yang berpotensi memiliki bias yang besar (Kansal dan Singh, 2018). Sebagaimana pula yang dinyatakan oleh Ozen dan Ersoy (2019) dan Baker, dkk. (2018) bahwa tingkat bias investor tergantung pada tingkat literasi keuangan yang dimiliki. Individu yang lebih sedikit memperoleh edukasi terkait keuangan, termasuk mahasiswa, akan memiliki bias yang lenih tinggi, yang akan mengarah pada keputusan investasi yang irasional (Pradikasari dan Isbanah, 2018).

\section{Kajian Literatur}

\section{Behavioral Finance Theory}

Behavioral finance theory merupakan studi yang mempelajari bagaimana manusia menyikapi atas informasi yang diterima sebagai dasar pengambilan keputusan dengan memperhatikan tingkat risiko dan mengoptimalkan tingkat pengembalian. Menurut Nofsinger (2001), perilaku keuangan (behavioral finance) merupakan teori yang mempelajari bagaimana manusia melakukan investasi atau yang berhubungan dengan keuangan dipengaruhi oleh faktor psikologi. Pompian (2012) menyatakan bahwa faktor psikologis terbagi menjadi dua, yaitu cognitive bias dan emotional bias. Cognitive bias adalah kesalahan dalam berpikir ketika individu mengumpulkan, memproses dan menginterpretasikan informasi. Kesalahan ini dapat muncul karena informasi yang tidak benar atau terburu-buru dalam 
memilih solusi, sehingga berdampak pada kesalahan dalam pengamblian keputusan. Sementara itu, emotional bias adalah distorsi pengambilan keputusan karena faktor emosional (Baker, 2017). Pengambilan keputusan investasi yang didominasi oleh faktor kognitif dan emosi ini mengakibatkan investor bertindak secara irasional.

\section{Self-Attribution Bias}

Self-attribution bias mengacu pada perilaku investor yang ketika mengalami keuntungan cenderung mengakui bahwa keberhasilan tersebut berasal dari kemampuan dan pengetahuan mereka. Sebaliknya, ketika mengalami kerugian, investor cenderung menyalahkan orang lain atau beranggapan bahwa kegagalan yang terjadi merupakan kesalahan faktor eksternal yang berada di luar kendali mereka (Mushinada dan Veluri, 2019). Deaves dkk. (2010) mengungkapkan bahwa keberhasilan di masa lalu memicu munculnya self-attribution bias, sedangkan kegagalan di masa lalu merupakan bagian yang diabaikan. Hal ini berarti self-attribution bias sangat rentan terjadi pada investor yang memiliki pengalaman dalam melakukan investasi. Self-attribution bias yang berlebihan mengakibatkan seorang investor akan salah dalam menginterpretasikan informasi yang akurat.

\section{Mental Accounting}

Mental accounting merupakan proses kognitif yang digambarkan dengan sikap seseorang yang selalu berfikir untuk melakukan evaluasi terhadap investasinya dengan memilah-milah setiap pengeluaran dan pendapatannya ke dalam pos-pos tertentu. Nofsinger (2005) mengatakan bahwa investor yang memiliki mental accounting pada saat melakukan pengambilan keputusan investasi selalu mempertimbangkan cost dan benefit dari keputusannya. Tujuannya adalah memaksimalkan pengembalian (return) dan meminimalkan risiko (Zahera dan Bansal, 2018)). Investor merasa bahwa perilaku tersebut menjadikan mereka akan merasa aman karena dengan begitu mereka merasa terhindar dari risiko yang besar.

\section{Familiarity Bias}

Familiarity bias merupakan perilaku seorang investor yang selalu memberi penilaian terhadap sesuatu yang kemudian mengambil keputusan hanya berdasarkan apa yang dikenali dan familier baginya. Huberman (2001) menyatakan familiarity bias dalam pasar modal ialah sebagai kecenderungan investor untuk membeli saham tertentu yang kemudian membentuk portofolio secara tidak terdiversifikasi karena pemilihan berdasarkan kedekatan geografis, kedekatan profesional, dan patriotisme budaya. Pada akhirnya, keputusan investasi yang hanya berdasar pada familiarity menyebabkan investor hanya berpacu pada sisi positif atau negatif dari produk dan merek dari perusahaan tertentu, yang mana keputusan tersebut jelas tidak menggambarkan fundamental perusahaan dan dapat mengakibatkan keuntungan yang diperoleh investor tidak sebanding dengan yang diharapkan.

\section{Pengambilan Keputusan Investasi}

Pengambilan keputusan investasi merupakan suatu tindakan seorang investor dalam mempertimbangkan perencanaan-perencanaan yang mereka buat secara matang agar memberi keuntungan di masa yang akan datang. Pencapaian yang diperoleh investor tergantung dari tindakan seperti apa yang mereka lakukan. Keputusan investasi yang diambil pun dapat dipengaruhi oleh beberapa faktor, seperti pengalaman keuntungan investor di masa lalu dan prediksi mereka terhadap keuntungan investasi yang akan diperoleh di masa yang akan datang (Virclis, 2013).

Terdapat dua proses yang mempengaruhi investor dalam pengambilan keputusan investasi, yaitu pengambilan keputusan secara rasional dan irasional. Pengambilan keputusan secara rasional adalah pengambilan keputusan atas dasar logika dan informasi-informasi yang berkaitan dengan investasi tersebut. Namun, faktanya adalah walaupun investor sudah rasional, tetap terdapat faktor psikologis yang berperan besar dalam pengambilan keputusan investasi (Utami, 2005). Hal inilah yang kemudian memicu adanya pengambilan keputusan secara irasional. Pengambilan keputusan secara irasional diartikan sebagai pengambilan keputusan yang hanya berdasarkan perasaan pribadi. Perilaku investor yang irasional bersifat subjektif yang artinya dalam melakukan pengambilan keputusan investasi, investor selalu bergantung pada kondisi keuangan, persepsi investor terhadap risiko, dan kemampuan investor dalam menganalisis teknik investasinya. 


\section{Self-Attribution Bias dan Pengambilan Keputusan Investasi}

Self-attribution bias merupakan overconfidence bias yang merupakan bagian dari emotional bias. Selfattribution bias sangat berpengaruh ketika investor mengalami kesuksesan di masa lalu atau ketika keputusan yang diambil ternyata mengalami keuntungan (Nofsinger dan Hirschey, 2008). Kondisi ini membuat investor akan beratribusi bahwa kesuksesan tersebut merupakan kemampuan atas diri sendiri sehingga menimbulkan tingkat overconfidence yang semakin tinggi. Sebaliknya, jika keputusan yang dibuat mengalami kegagalan atau kerugian, maka investor akan beratribusi bahwa kegagalan tersebut merupakan bagian dari nasib buruk atau faktor eksternal yang tidak dapat dikendalikan. Oleh karena itu, self-attribution bias menjadikan investor memiliki rasa percaya diri yang tinggi terhadap diri sendiri ketika berhasil dan cenderung menyalahkan faktor luar yang bukan kendalinya yang memberi pengaruh cukup besar terhadap investor dalam pengambilan keputusan investasi. Persepsi seperti inilah yang kemudian membuat para investor kesulitan untuk melakukan evaluasi dalam keputusan investasinya karena adanya keengganan dalam pengendalian diri.

Ditemukan bahwa self-attribution bias memiliki pengaruh positif terhadap keputusan investasi (Mahina, dkk., 2018; Mittal, 2019). Kemudian Cremers dan Pareek (2011) juga menyatakan bahwa selfattribution bias mempengaruhi investor ketika melakukan transaksi di bursa saham dengan hanya menerima informasi pribadi dan menolak informasi publik. Investor percaya bahwa keputusannya akan memberi keuntungan yang sama seperti sebelumnya.

H1: Terdapat pengaruh positif self-attribution bias terhadap pengambilan keputusan investasi.

\section{Mental Accounting dan Pengambilan Keputusan Investasi}

Mental accounting merupakan bentuk menghindari rugi dan mencari saham yang aman, yang menjadi bagian dari cognitive bias. Mental accounting mengacu pada pengodean, pengkategorisasian, dan pengevaluasian keputusan keuangan (Pompian, 2006). Hal tersebut menjadi proses mental accounting ketika seseorang mencoba untuk membatasi alokasi anggaran untuk pengeluarannya dengan mempertimbangkan gain (keuntungan) yang akan diperoleh.

Mental accounting berpengaruh terhadap keputusan investasi (Shams, dkk., 2012; Sumtoro dan Anastasia, 2015). Investor yang memiliki mental accounting akan selalu mengkalkulasi keuangan mereka setiap saat. Ketika mengambil keputusan investasi, investor individu berusaha untuk mengakumulasi kerugian dan memperhitungkan potensi keuntungan yang dapat diperoleh.

$\mathrm{H} 2$ : Terdapat pengaruh positif mental accounting terhadap pengambilan keputusan investasi.

\section{Familiarity Bias dan Pengambilan Keputusan Investasi}

Familiarity bias merupakan kecenderungan seseorang untuk melakukan penilaian dan memilih terhadap sesuatu yang hanya mereka kenali. Nofsinger (2005) menyatakan bahwa dalam konteks investasi, investor akan cenderung melakukan investasi pada perusahaan atau produk investasi yang telah dikenal atau diketahui. Investor merasa dapat memperkirakan tingkat return dan risiko yang diterima melalui perkiraan (feeling) dan informasi yang mereka miliki. Bias ini mengakibatkan investor cenderung memberi penilaian bahwa sesuatu yang telah dikenali sebelumnya jauh lebih baik ketimbang sesuatu yang baru atau belum dikenali. Sikap pengambilan keputusan dengan memilih sesuatu yang sudah diketahui mengakibatkan pengambilan keputusan menjadi tidak akurat. Hal ini merupakan bagian dari cognitive bias dalam behavioral finance theory.

Familiarity bias berpengaruh positif terhadap keputusan investasi (Magdalena, dkk., 2018), baik dalam kondisi pasar uptrend maupun downtrend (Djojopranoto dan Mahadwartha, 2016). Familiarity bias menyebabkan seseorang membuat keputusan bahwa perusahaan yang dikenali tidak akan memberi kerugian yang besar dan memberi risiko yang rendah dibandingkan dengan perusahaan yang kurang dikenali.

H3: Terdapat pengaruh positif familiarity bias terhadap pengambilan keputusan investasi.

\section{Metode Penelitian}

Penelitian ini menggunakan pendekatan kuantitatif yang menjelaskan pengaruh variabel independen terhadap variabel dependen. Sumber data menggunakan data primer yang mana data yang diperoleh secara langsung dari objek penelitian. Kemudian teknik pengumpulan data adalah dengan cara memberi 
seperangkat pertanyaan atau pernyataan tertulis kepada responden (Sugiyono, 2016). Dalam penelitian ini kuesioner disebarkan secara online melalui googleform.

Studi ini memiliki empat variabel, yaitu self-attribution bias (X1), mental accounting (X2), familiarity bias (X3), dan pengambilan keputusan investasi (Y). Self-attribution bias (X1) merupakan kesalahan kognitif yang menyebabkan seorang investor berperilaku overestimate dalam pengambilan keputusan investasinya karena kepercayaan pada diri sendiri. Self-attribution bias diukur dengan menggunakan daftar pernyataan dari Mahina, dkk (2018) dengan indikator, yaitu yakin bahwa keberhasilan yang terjadi merupakan faktor internal dan kegagalan yang terjadi disebabkan faktor eksternal.

Mental accounting (X2) didefinisikan sebagai proses kognitif dalam mengatur dan mengevaluasi keuangan dengan membuat pos-pos yang berbeda dalam setiap aktivitas keuangannya. Mental accounting diukur menggunakan daftar pernyataan dari Nofsinger (2005) dengan indikator, yaitu biaya yang dikeluarkan dan keuntungan yang diperoleh.

Familiarity bias (X3) yang merupakan perilaku investor yang ketika mengambil keputusan berdasarkan hal-hal yang telah mereka kenali saja. Familiarity bias diklasifikasikan sebagai kesalahan kognitif karena ketika mengambil keputusan hanya berdasarkan pengetahuan yang dimiliki. Familiarity bias diukur menggunakan daftar pernyataan dari Djojopranoto dan Mahadwartha (2016) dengan indikator, yaitu keakraban terhadap sesuatu yang dikenal dan optimis terhadap keputusan yang dibuat.

Pengambilan keputusan investasi (Y) yang diartikan sebagai tindakan seorang investor dalam mempertimbangkan perencanaan-perencanaan yang mereka buat secara matang agar memberi keuntungan di masa yang akan datang. Pengambilan keputusan investasi diukur menggunakan daftar pernyataan dari Pompian (2012) dan Puspitasari (2018) dengan indikator, yaitu return/tingkat pengembalian investasi yang diharapkan dan sikap terhadap risiko.

Alat ukur penelitian ini ialah menggunakan skala likert dengan lima (5) jenjang skala. Skala dimulai dari skor satu (1) yang dinyatakan dengan Sangat Tidak Setuju sampai skor lima (5) yang dinyatakan dengan Sangat Setuju.

Populasi dalam penelitian ini adalah seluruh mahasiswa yang terdaftar sebagai investor saham di BEI (Bursa Efek Indonesia) dan tergabung ke dalam komunitas-komunitas yang ada di kota Malang, yaitu ISP (Investor Saham Pemula), YCMC (Youth Capital Market Community), dan ALSTO (Alkahfi Stock). Dipilihnya komunitas tersebut dikarenakan keaktifan anggota dalam berdiskusi mengenai perkembangan saham melalui media sosial Whatsapp dan Line serta anggota yang bergabung didominasi oleh kalangan mahasiswa. Jumlah mahasiswa yang tergabung pada komunitas-komunitas tersebut sekitar 288 mahasiswa. Kemudian, sampel ditentukan dengan metode purposive sampling, yaitu teknik pengambilan sampel yang pengambilan datanya berdasarkan kriteria antara lain: 1) mahasiswa yang benar-benar masih aktif melakukan investasi saham, 2) mahasiswa yang telah memiliki pengalaman bertransaksi saham minimal 1 bulan, dan 3) berdomisili di kota Malang.

Tahapan awal yang dilakukan adalah melakukan uji instrumen yang dilakukan kepada 30 responden di luar sampel penelitian. Hasil dari uji instrumen kemudian diuji validitas dan reliabilitasnya. Setelah data dan kuesioner memenuhi kriteria validitas dan reliabilitas, kuesioner disebarkan kembali dan diisi oleh 44 responden. Data tersebut kemudian diuji asumsi klasik yang terdiri dari uji normalitas, uji mulitkolinearitas, dan uji heteroskedastisitas. Setelah memenuhi asumsi klasik, dilakukan analisis data yaitu uji pengaruh secara simultan dengan regresi linier berganda untuk mengetahui apakah selfattribution bias, mental accounting, dan familiarity bias berpengaruh positif terhadap pengambilan keputusan investasi.

\section{Hasil dan Pembahasan}

\section{Analisis Deskriptif Data}

Berdasarkan Tabel 1, dari jumlah responden sebanyak 44, nilai rata-rata variabel self-attribution bias adalah sebesar 24,93 poin untuk 7 pernyataan, sehingga rata-rata jawaban responden adalah 3,56. Angka ini menunjukkan responden cukup memiliki kepercayaan diri yang tinggi bahwa keberhasilan investasi merupakan hasil kemampuan dirinya. Nilai rata-rata variabel mental accounting adalah sebesar 31,02 poin untuk 8 pernyataan, sehingga rata-rata jawaban responden adalah 3,88. Angka ini menunjukkan responden memang menghitung biaya dan keuntungan sebelum mengambil keputusan 
investasi. Nilai rata-rata variabel familiarity bias adalah sebesar 29,89 poin untuk 8 pernyataan, sehingga rata-rata jawaban responden adalah 3,73. Angka ini menunjukkan responden memang akan memilih dan lebih optimis untuk investasi pada perusahaan yang dikenali.

Tabel 1 Hasil Statistik Deskriptif

\begin{tabular}{|c|c|c|c|c|c|}
\hline & $\mathrm{N}$ & Minimum & Maksimum & $\begin{array}{c}\text { Rata- } \\
\text { rata }\end{array}$ & $\begin{array}{l}\text { Standar } \\
\text { Deviasi }\end{array}$ \\
\hline Self-Attribution Bias & 44 & 18 & 33 & 24,93 & 3,323 \\
\hline Mental Accounting & 44 & 20 & 38 & 31,02 & 4,234 \\
\hline Familiarity Bias & 44 & 22 & 39 & 29,89 & 4,205 \\
\hline $\begin{array}{c}\text { Pengambilan Keputusan } \\
\text { Investasi }\end{array}$ & 44 & 21 & 38 & 30,50 & 4,321 \\
\hline
\end{tabular}

Sumber : Hasil Olah Statistik

\section{Uji Validitas dan Uji Reliablitas}

Data telah memenuhi uji validitas dan uji reliabilitas. Uji validitas dengan menggunakan tabel korelasi product moment dari pearson menunjukkan bahwa secara keseluruhan item pernyataan yang digunakan dalam kuesioner adalah valid dengan tingkat signifikansi 0,05 dan $r$ hitung $>\mathrm{r}$ hitung $(0,361)$. Berdasarkan uji reliabilitas, nilai koefisien cronbach alpha dari keempat variabel $>0,60$, sehingga instrumen dinyatakan reliabel.

\section{Uji Asumsi Klasik}

Uji normalitas dilakukan dengan uji Kolmogorov-Smirnov menggunakan SPSS 24. Berdasarkan Tabel 2, nilai signifikansinya adalah $0,870>0,05$ yang berarti bahwa data telah memenuhi asumsi normalitas. Berdasarkan Tabel 3, nilai VIF untuk masing-masing variabel bebas, yaitu self-attribution bias, mental accounting, dan familiarity bias < 10 dan nilai tolerance berada di antara 0,10 dan 1 . Hasil ini menunjukkan bahwa tidak terdapat multikolinearitas antar variabel bebas dalam model regresi.

Tabel 2 Hasil Uji Normalitas

\begin{tabular}{lcc}
\hline & $\begin{array}{c}\text { Uji Kolmogorov- } \\
\text { Smirnov }\end{array}$ & $\begin{array}{c}\text { Asymp. Sig. (2- } \\
\text { tailed) }\end{array}$ \\
\hline $\begin{array}{l}\text { Unstandardized } \\
\text { Residual }\end{array}$ & 0,596 & 0,870 \\
\hline
\end{tabular}

Sumber: Hasil Olah Statistik

Tabel 3 Hasil Uji Multikolinearitas

\begin{tabular}{|c|c|c|}
\hline \multirow[t]{2}{*}{ Variabel Independen } & \multicolumn{2}{|c|}{ Collinearity Statictics } \\
\hline & Tolerance & VIF \\
\hline Self-Attribution Bias & 0,619 & 1,616 \\
\hline Mental Accounting & 0,767 & 1,303 \\
\hline Familiarity Bias & 0,659 & 1,518 \\
\hline
\end{tabular}

Sumber: Hasil Olah Statistik

Tabel 4 Hasil Uji Heteroskedastisitas dengan Uji Glejser

\begin{tabular}{lccccc}
\hline \multirow{2}{*}{ Variabel Independen } & \multicolumn{2}{c}{$\begin{array}{l}\text { Unstandardized } \\
\text { Coefficients }\end{array}$} & $\begin{array}{c}\text { Standardized } \\
\text { Coefficients }\end{array}$ & $\mathrm{t}$ & \multirow{2}{*}{ Sig. } \\
\cline { 2 - 4 } & \multicolumn{1}{c}{$\mathrm{B}$} & Std. Error & Beta & & \\
\hline (Constant) & 0,587 & 2,226 & & 0,264 & 0,793 \\
Self-Attribution Bias & $-0,081$ & 0,093 & $-0,170$ & $-0,867$ & 0,391 \\
Mental Accounting & 0,075 & 0,065 & 0,202 & 1,145 & 0,259 \\
Familiarity Bias & 0,036 & 0,071 & 0,096 & 0,506 & 0,615 \\
\hline \multicolumn{7}{c}{ Variabel Dependen: ABSRESID } \\
\end{tabular}


Tabel 4 menunjukkan bahwa variabel self-attribution bias memiliki nilai signifikansi sebesar 0,391, mental accounting sebesar 0,259, dan familiarity bias sebesar 0,615 yang ketiganya memiliki nilai signifikansi lebih dari 0,05. Hasil ini menunjukkan tidak ada heteroskedastisitas. Dengan demikian, dapat disimpulkan bahwa secara keseluruhan model regresi dalam penelitian ini telah memenuhi uji asumsi klasik.

\section{Uji Hipotesis}

Berdasarkan Tabel 5, seluruh variabel independen, yaitu self-attribution bias, mental accounting, dan familiarity bias berpengaruh terhadap pengambilan keputusan investasi yang tampak dari nilai signifikansi $<0,05$. Seluruh variabel independen berpengaruh positif yang tampak dari nilai beta positif. Selin itu, adjusted $R$-square sebesar 0,653. Angka ini menunjukkan bahwa kontribusi self-attribution bias, mental accounting, dan familiarity bias sebagai faktor yang mempengaruhi pengambilan keputusan investasi adalah sebesar 65,3\%.

Tabel 5 Hasil Analisis Regresi Linier Berganda

\begin{tabular}{lcrccc}
\hline Variabel Independen & \multicolumn{2}{c}{ Unstandardized } & \multirow{2}{*}{$\begin{array}{c}\text { Standardized } \\
\text { Coefficients }\end{array}$} & $\mathrm{t}$ & \multirow{2}{*}{ Sig. } \\
\cline { 2 - 4 } & $\mathrm{B}$ & Std. Error & Beta & & \\
\cline { 2 - 4 } (Constant) & $-1,093$ & 3,690 & & $-0,296$ & 0,769 \\
Self-Attribution Bias & 0,435 & 0,154 & 0,334 & 2,823 & 0,007 \\
Mental Accounting & 0,298 & 0,109 & 0,292 & 2,746 & 0,009 \\
Familiarity Bias & 0,385 & 0,118 & 0,375 & 3,265 & 0,002 \\
\hline
\end{tabular}

Variabel Dependen: Pengambilan Keputusan Investasi

Sumber: Hasil Olah Statistik

\section{Pembahasan}

Pengaruh Self-Attribution Bias terhadap Pengambilan Keputusan Investasi

Berdasarkan hasil pada Tabel 5, hipotesis pertama diterima, yang mana variabel self-attribution bias berpengaruh positif terhadap pengambilan keputusan investasi. Hal ini berarti bahwa semakin tinggi self-attribution bias dalam diri investor, maka akan meningkatkan pengambilan keputusan investasi.

Self-attribution bias yang tinggi dapat menyebabkan investor untuk melakukan kesalahan ketika menginterpretasikan informasi yang didapat dengan investasi yang dilakukan. Hal ini didukung dengan jawaban responden, yaitu "keuntungan yang diperoleh merupakan kemampuan saya dalam menganalisis investasi" yang mendapatkan nilai maksimum sebesar 182 dengan nilai rata-rata 4,1. Nilai rata-rata yang tinggi ini berarti ketika mendapat keberhasilan, responden dalam penelitian ini yaitu mahasiswa sangat percaya bahwa keuntungan yang diperoleh merupakan hasil dari kemampuan analisis yang bagus terkait dengan naik dan turunnya harga saham, sehingga mereka merasa dapat memprediksi hasil return yang tinggi dengan tingkat risiko yang kecil.

Hasil dari penelitian ini sejalan dengan behavioral finance theory yang menyatakan bahwa saat mengambil keputusan investasi, investor cenderung dipengaruhi oleh faktor psikologis mereka yang didukung dengan pernyataan Nofsinger dan Hirschey (2008) ketika investor mengalami kesuksesan di masa lalu atau ketika keputusan yang diambil ternyata berhasil mendatangkan keuntungan, maka investor akan cenderung beratribusi bahwa kesuksesann tersebut merupakan kemampuan diri sendiri, sehingga menimbulkan tingkat overconfidence yang semakin tinggi.

Sebaliknya, jika keputusan yang dibuat mengalami kegagalan atau kerugian, maka investor akan beratribusi bahwa kegagalan tersebut merupakan nasib buruk atau faktor eksternal yang tidak dapat dikendalikan yang kemudian membuat investor enggan untuk melakukan evaluasi terhadap investasinya. Hasil penelitian ini mendukung penelitian Mahina, dkk (2018) dan Cremers dan Pareek (2011) yang menyatakan bahwa terdapat pengaruh self-attribution bias dalam pengambilan keputusan investasi. 


\section{Pengaruh Mental Accounting terhadap Pengambilan Keputusan Investasi}

Berdasarkan hasil pada Tabel 5, hipotesis kedua diterima, yang mana variabel mental accounting berpengaruh positif terhadap pengambilan keputusan investasi. Hal ini berarti bahwa semakin besar mental accounting dalam diri investor, maka akan meningkatkan pengambilan keputusan investasi.

Pompian (2006) menyatakan bahwa mental accounting mengacu pada aktivitas pengodean, pengkategorisasian, dan pengevaluasian keputusan keuangan. Tujuan pengkategorian tersebut sebagai bentuk self-control agar keuangan mereka tetap aman dan bekerja sesuai yang diharapkan. Hal ini didukung oleh jawaban responden yang tinggi pada pernyataan, yaitu "saya selalu menghitung keuntungan yang diperoleh dari investasi saya" yang menunjukkan nilai maksimum 185 dengan nilai rata-rata 4,2. Hal ini berarti responden yaitu mahasiswa akan selalu menghitung dan melakukan pertimbangan atas segala kemungkinan yang dapat terjadi pada investasinya. Ketika mendapatkan keuntungan khususnya, mereka berusaha mengklasifikasikan keuntungan yang didapat agar rencana yang dibuat dapat memberi keuntungan yang lebih di masa depan.

Hasil penelitian ini sesuai dengan behavioral finance theory yang menyatakan bahwa pendekatan mental accounting yang dinyatakan Thaler (1985) merupakan perilaku kognitif seseorang yang digunakan untuk membuat kategori serta mengevaluasi situasi ketika dapat diprediksi kemungkinan hasil, khususnya bagaimana mengkombinasikan kemungkinan-kemungkinan tersebut. Hal tersebut dilakukan agar investor dapat merencanakan dan mengelola keuangannya dengan baik dan hati-hati. Dengan melakukan pengelompokkan dalam masing-masing yang dimiliki, investor akan merasa akan fokus pada bagaimana seharusnya mengevaluasi suatu situasi yang dihadapinya. Hasil penelitian ini mendukung penelitian Sumtoro dan Anastasia (2015) dan Shams dkk. (2012) yang mendukung adanya pengaruh mental accounting dalam pengambilan keputusan investasi.

\section{Pengaruh Familiarity Bias terhadap Pengambilan Keputusan Investasi}

Berdasarkan hasil pada Tabel 5, hipotesis ketiga diterima, yang mana variabel familiarity bias berpengaruh positif terhadap pengambilan keputusan investasi. Investor yang terpengaruh oleh familiarity bias secara berlebihan mengakibatkan terjadinya peningkatan pengambilan keputusan yang irasional (Mittal, 2019).

Familiarity bias merupakan perilaku investor yang menilai sesuatu berdasarkan yang sudah dikenalinya (Nofsinger, 2005). Investor yang terkena bias ini hanya akan percaya dan beranggapan bahwa keputusan yang mereka buat atas sesuatu yang dikenali adalah cara terbaik agar investasi yang dilakukan tidak akan berada pada tingkat risiko yang berbahaya dan tetap dapat menghasilkan keuntungan yang diharapkan. Hal ini didukung dengan jawaban responden pada pernyataan kuesioner, yaitu "pada saat pasar modal mengalami uptrend, saya yakin saham yang saya miliki akan memberi return yang tinggi" dengan nilai maksimum 175 dan nilai rata-rata 4,0. Artinya, investor yang mengalami familiarity bias memiliki kepercayaan yang tinggi pada keputusan yang mereka buat.

Responden pada penelitian ini, yaitu mahasiswa ketika menjadi investor sangat percaya jika melakukan investasi pada perusahaan yang familier, keuntungan yang diperoleh akan maksimal terutama ketika pasar mengalami uptrend. Pada kondisi ini mereka akan beranggapan keuntungan yang didapatkan pun dapat melebihi ekspektasi yang dibuat.

Penelitian ini mendukung behavioral finance theory oleh Pompian (2006) yang menyatakan bahwa faktor psikologi mempengaruhi tingkah laku keuangan para investor. Investor yang berperilaku familiarity bias cenderung mengambil keputusan hanya pada sesuatu yang telah mereka kenali. Hasil penelitian ini mendukung penelitian yang dilakukan oleh Djojopranoto dan Mahadwartha (2016) dan Magdalena, dkk (2018) yang menyatakan bahwa familiarity bias mempengaruhi investor dalam mengambil keputusan investasi.

\section{Kesimpulan}

Self-attribution bias, mental accounting, dan familiarity bias berpengaruh positif terhadap pengambilan keputusan investasi mahasiswa di kota Malang. Investor mahasiswa menganggap bahwa keberhasilan investasi yang diperoleh merupakan dampak dari kemampuan diri mereka dalam menganalisis investasi, mempertimbangkan untung rugi sebelum melakukan investasi, dan cenderung akan berinvestasi pada perusahaan yang dikenali. Beberapa sikap tersebut menimbulkan bias dan mempengaruhi pengambilan keputusan investasi yang irasional. 
Keterbatasan dalam penelitian ini adalah penelitian ini hanya dilakukan pada komunitaskomunitas yang ada di kota Malang, seperti ISP, YCMC, dan ALSTO, serta penyebaran kuesioner hanya dilakukan secara online. Lingkup responden menjadi kurang luas dan tidak adanya tatap muka dalam pengisian data mengakibatkan kemungkinan responden hanya sekedar mengisi kuesioner tanpa membaca pernyataan dengan baik.

Berdasarkan hasil dan keterbatasan pada penelitian ini, diharapkan penelitian selanjutnya dapat menambah bias-bias atau variabel yang berkaitan dengan teori behavioral finance, seperti cognitive dissonance bias dan illusion of control bias. Kemudian, sebaiknya penelitian selanjutnya dilakukan pada perusahaan pengelola efek yang memiliki jumlah investor yang lebih bermacam-macam karakteristiknya dan peneliti perlu mendampingi responden saat melakukan pengisian kuesioner agar data yang didapat lebih akurat.

Bias yang dimiliki oleh investor mahasiswa dapat dikarenakan literasi keuangan yang diperoleh lebih sedikit. Oleh karena itu, hasil penelitian ini memberikan implikasi perlunya peningkatan bahan pembelajaran investasi keuangan. Mahasiswa perlu memahami bagaimana pengambilan keputusan investasi itu dapat menjadi bias karena minimnya pengetahuan dan pengalaman. Dengan demikian, penelitian ini berkontribusi bagi perkembangan pendidikan investasi keuangan.

\section{Daftar Pustaka}

Baker, H. K. (2017). How Behavioral Biases Can Hurt Your Investing. In Investment Traps Exposed, 107-145. https://www.emerald.com/insight/publication/doi/10.1108/9781787142527.

Baker, H. K., Kumar, S., Goyal, N., dan Gaur, V. (2018). How financial Literacy and Demographic Variables Relate to Behavioral Biases. Managerial Finance, 45(1), 124-146. https://doi.org/10.1108/MF-01-2018-0003.

Cremers, M. \& Pareek, A. (2011). Can Overconfidence and Biased Self-Attribution Explain the Momentum, Reversal, and Share Issuance Anomalies? Evidence from Short-Term Institusional Investors. SSRN Electronic Journal. DOI: 10.2139/ssrn.1571191.

De Vries, A., Erasmus, P. D., \& Gerber, C. (2017). The Familiar Versus the Unfamiliar: Familiarity Bias Amongst Individual Investors. Acta Commercii, 17(1), 73-85. DOI:10.4102/ac.v17i1.366.

Deaves, R., Lüders, E., \& Schröder, M. (2010). The Dynamics of Overconfidence: Evidence from Stock Market Forecast. Discussion Paper No. 05-83, Center for European Economics Research. ftp://ftp.zew.de/pub/zew-docs/dp/dp0583.pdf.

Djojopranoto, R. R. \& Mahadwartha, P. A. (2016). Pengujian Bias Perilaku: Gambler's Fallacy, Halo Effect, dan Familiarity Effect di Pasar Modal Indonesia. Jurnal Akuntansi dan Keuangan Indonesia, 13(2), 142-159. http://dx.doi.org/10.21002/jaki.2016.08.

Hsu, Y. \& Shiu, C. (2007). Investors' Overconfidence in Primary Markets. 20th Australasian Finance \& Banking Conference 2007 Paper. https://papers.ssrn.com/sol3/papers.cfm?abstract_id=100934.

Huberman, G. (2001). Familiarity Breeds Investment. The Review of Financial studies, 14(3), 659-680. https://doi.org/10.1093/rfs/14.3.659.

Kansal, P. dan Singh, S. (2018). Determinants of Overconfidence Bias in Indian Stock Market. Qualitative Research in Financial Markets, 10(4), 381-394. https://doi.org/10.1108/QRFM-032017-0015.

Kontan.co.id. 2018. Investor Pasar Modal per Maret 2018 Meningkat 8,34\%. https://investasi.kontan.co.id/news/investor-pasar-modal-per-maret-2018-meningkat-834.

Magdalena, B., Susanti, \& Yanti, Y. (2018). Perilaku Investor Muslimah di Pasar Modal Syariah di Lampung. Jurnal Bisnis Darmajaya, 4(1), 26-44. https://webcache.googleusercontent.com/search?q=cache:oxVpAotmOqQJ:https://jurnal.darmaj aya.ac.id/index.php/JurnalBisnis/article/download/1325/831+\&cd=3\&hl=en\&ct=clnk\&gl=id.

Mahina, J. N., Muturi, W., \& Florence, M. (2018). Effect of Self-Attribution Bias in The Rwandan Stock Market. Global Journal of Management and Business Research. 18(2), 55-63. https://globaljournals.org/GJMBR_Volume18/6-Effect-of-Self-Attribution-Bias.pdf.

Mittal, S. K. (2019). Behavior Biases and Investment Decision: Theoretical and Research Framework. Qualitative Research in Financial Markets, Vol. ahead-of-print No. ahead-of-print. https://doi.org/10.1108/QRFM-09-2017-0085. 
Mushinada, V. N. C. dan Veluri, V. S. S. (2019). Elucidating Investors Rationality and Behavioural Biases in Indian Stock Market. Review of Behavioral Finance, 11(2), 201-219. https://doi.org/10.1108/RBF-04-2018-0034.

Nofsinger, J. R. (2001). The Impact of Public Information on Investors. Journal of Banking \& Finance, 25(7), 1339-1366. https://doi.org/10.1016/S0378-4266(00)00133-3.

Nofsinger, J. R. (2005). Psychology of Investing (Second Edition). New Jersey: Prentice-Hall Inc.

Nofsinger, R. J. \& Hirschey, M. (2008). Investment: Analysis and Behavioral. New York: McGrawHill.

Ozen, E. dan Ersoy, G. (2019). Ch 7 The Impact of Financial Literacy on Cognitive Biases of Individual Investors, Grima, S., Özen, E., Boz, H., Spiteri, J. dan Thalassinos, E. (Ed.) Contemporary Studies in Economic and Financial Analysis, 101, 77-95. https://doi.org/10.1108/S1569375920190000101007.

Pompian, M. (2006). Behavioral Finance and Wealth Management. New York: John Wiley \& Sohn, Inc..

Pompian, M. (2012). Behavioral Finance and Wealth Management. How To Build Investment Strategies That Account For Investor Biases. New York: John Wiley \& Sons.

Pradikasari, E. \& Isbanah, Y. (2018). Pengaruh Financial Literacy, Illusion of Control Overconfidence, Risk Tolerance, dan Risk Perception terhadap Keputusan Investasi pada Mahasiswa di Kota Surabaya. Jurnal Ilmu Manajemen, 6(4), 424-434. http://jurnalmahasiswa.unesa.ac.id/index.php/jim/article/view/24408/22333

Puspitasari, D. A. \& Dewi, F. R. (2018). Pengaruh Literasi Keuangan, Overconfidence, dan Risk Tolerance Terhadap Keputusan Investasi Produk Pasar Modal. Skripsi pada Fakultas Ekonomi Institut Pertanian Bogor di Bogor. http://repository.ipb.ac.id/handle/123456789/94565.

Ratnadewi, F. (2014). Behavioral Finance dalam Keputusan Investasi Saham (Studi Bias Perilaku Pada Investasi Mahasiswa Di Kota Bandung). Tesis pada Universitas Pendidikan Indonesia di Bandung. http://repository.upi.edu/11495/.

Shams, M. F., Kordlouie, H., Dezfuli, H. K. (2012). The Effect of Mental Accounting on Sales Decisions of Stockholders in Tehran Stock Exchange. World Applied Sciences Journal. 20(6), 842-847. DOI: 10.5829/idosi.wasj.2012.20.06.2763.

Shefrin, (2002). Beyond Greed and Fear: Understanding Behavioral Finance and the Psychology of Investing. Oxford: Oxford University.

Sugiyono. (2016). Metode Penelitian Kuantitatif, Kualitatif dan R\&D. Bandung: PT Alfabet.

Sumtoro, A. \& Anatasia, N. (2015). Perilaku Keuangan dalam Pengambilan Keputusan Berinvestasi Properti Residensial di Surabaya. Finesta, 3(1): 41-45. http://publication.petra.ac.id/index.php/manajemen-keuangan/article/view/2960.

Thaler, R. (1985). Mental Accounting and Consumer Choice. Journal Marketing Science, 4(3), 199214. https://doi.org/10.1287/mksc.4.3.199.

Utami, W. (2005). Pengaruh Manajemen Laba terhadap Biaya Modal Ekuitas (Studi Pada Perusahaan Publik Sektor Manufaktur). Simposium Nasional Akuntansi VIII, Solo.

Virclis, A. (2013). Investment Decision Making and Risk. Procedia Economics and Finance, 6, 169177. https://doi.org/10.1016/S2212-5671(13)00129-9.

Zaheera, S. A. dan Bansal, R. (2018). Do Investors Exhibit Behavioral Biases in Investment Decision Making? A Systematic Review. Qualitative Research in Financial Markets, 10(2), 210-251. https://doi.org/10.1108/QRFM-04-2017-0028.

Mushinada, V. N. C. dan Veluri, V. S. S. (2018). Investors Overconfidence Behaviour at Bombay Stock Exchange. International Journal of Managerial Finance, 14(5), 613-632. https://doi.org/10.1108/IJMF-05-2017-0093.

*Email korespondensi:

vega.wafaretta.fe@um.ac.id 